\title{
Small businesses in the global market: evidence from the fashion system of Vicenza province (Italy)
}

D. Celetti

University of Padua, Padua, Italy; e-mail: david.celetti@unipd.it

\begin{abstract}
Relevance. The paper seeks to explore how small and medium handicrafts can successfully compete in the globalized market. It questions, in particular, the relevance of the territory, of industrial districts and of the use of information technology to create innovative approaches to production and marketing, and consolidate the territory's competitive position in global value chains. It highlights actual viable strategies for small and medium businesses operating in particularly complex sectors like those that are part of the "fashion system". Thus, the article deals with an important part of the national industry in the moment of world-wide crisis. Research Objective. The article discusses successful strategies of small firms in clothing and fashion industry. Its purpose is to verify if and how handicrafts operating in the sectors particularly exposed to international competition succeed in competing effectively in international markets. The study tests the thesis that local dimension does not necessarily represent a disadvantage in the age of globalization and that even handicrafts can play at the international level. The study also verifies the role of territory in granting unique competitive advantage in the global market. Data and Methods. The methodological approach combines analysis of statistical data with four case studies. The work combines analytical and empirical approaches to highlight how a single business can reach levels of excellence in troubled markets. Results. The study demonstrates that handicrafts can find spaces for growth in such declining sectors as cloth production in developed countries, provided that they succeed in focusing on niche markets through process, product, and marketing innovations; in using up-to-date technology; and in exploiting territorially embedded values. In this context technology emerges as a strategic tool as it lowers transaction costs and entrance barriers, offers innovative opportunities for re-organizing production processes, and enlarges potential markets. Industrial districts, then, continue to represent a viable strategic advantage in terms of flexibility, know-how, and cooperation. Finally, the brand "made in Italy" confirms its status as an internationally recognized synonym of quality and fashionable design, opening companies the way to high level, luxury niches.
\end{abstract}

\section{KEYWORDS}

textiles, fashion, clothing, industrial districts, handicraft, made in Italy, economic history

\section{ACKNOWLEDGEMENTS}

The research was supported by the project "The Economy of Excellence. Italian Handicraft in the International Networks: Traditional Knowledge, Technological Innovation and Communication Strategies $\left(19^{\text {th }}-20^{\text {th }}\right.$ Centuries)", University of Padua (IT), Department of Historical, Geographical Sciences and of the Antiquity.

\section{FOR CITATION}

Celetti, D. (2020) Small businesses in the global market: evidence from the fashion system of Vicenza province (Italy). R-economy, 6(2), 74-88. doi: 10.15826/recon.2020.6.2.007

\section{Малые предприятия в глобальном рынке: пример сектора моды провинции Виченца (Италия)}

\section{Д. Челетти}

Падуанский университет, Падуя, Италия; e-mail: david.celetti@unipd.it

\section{АННОТАЦИЯ}

Актуальность. Статья посвящена изучению того, как малые и средние ремесленные изделия могут успешно конкурировать на глобализированном рынке. В ней рассмотрены, в частности, роль территории, промышленных районов и использования информационных технологий для создания инновационных подходов к производству и сбыту, а также для укрепления конкурентоспособности территории в глобальных цепочках создания стоимости. Освещены актуальные жизнеспособные стратегии для малого и среднего бизнеса, работающего в особенно сложных секторах, таких как те, которые являются частью «системы моды». Таким образом, статья посвящена важной части итальянской промышленности в момент мирового кризиса. Цель исследования. В статье рассматриваются стратегии малых фирм в индустрии одежды и моды. Цель исследования состоит в том, чтобы проверить, успешно ли эти фирмы конкурируют на международных рынках. В исследовании проверяется тезис о том, что размер фирмы не обязательно является (C) Celetti, D., 2020

\section{КЛЮЧЕВЫЕ СЛОВА}

текстиль, мода, одежда, кластеры, ремесленная продукция, макроэкономика, экономическая история 
недостатком в эпоху глобализации и что даже ремесленные фирмы могут эффективно играть на международном уровне. Статья также подтверждает роль территории в предоставлении уникального конкурентного преимущества на мировом рынке. Данные и методы. Методологический подход объединяет теоретическое обсуждение выбранной научной литературы и статистических данных с углублённым анализом четырёх фирм. Работа сочетает в себе аналитические и эмпирические подходы, чтобы подчеркнуть, успешные стратегии отдельных фирм. Результаты. Исследование показывает, что ремесленные фирмы могут найти пространство для роста в таких сокращающихся секторах, как производство одежды в развитых странах, при условии, что им удастся сосредоточиться на нишевых рынках с помощью инноваций в процессах, продуктах и маркетинге; в использовании современных технологий; и в использовании территориально заложенных ценностей. В этом контексте технология становится стратегическим инструментом, поскольку она снижает операционные издержки и входные барьеры, предлагает инновационные возможности для реорганизации производственных процессов и расширяет потенциальные рынки. Таким образом, промышленные районы продолжают представлять собой жизненно важное стратегическое преимущество с точки зрения гибкости, ноу-хау и сотрудничества. Наконец, бренд «Сделано в Италии» подтверждает свой статус признанного во всем мире синонима качества и модного дизайна, открывая компаниям путь к нишам класса люкс высокого уровня.

\section{БЛАГОДАРНОСТИ}

Исследование было поддержано проектом «Экономика совершенства. Итальянское ремесло в международных сетях: традиционные знания, технологические инновации и коммуникационные стратегии (XIX - XX века)», Университет Падуи (ИТ), факультет исторических, географических наук и античности.

\section{ДЛЯ ЦИТИРОВАНИЯ}

Celetti, D. (2020) Small businesses in the global market: evidence from the fashion system of Vicenza province (Italy). R-economy, 6(2), 74-88. doi: 10.15826/recon.2020.6.2.007

\section{Introduction}

The Italian fashion system, even its most dynamic clusters, suffered from the prolonged decline of the early 2000s. Though traditionally strong and playing for decades a leading role in domestic economy, it started losing firms, employees, and turn-over. The negative trend affected both small and big companies in all the country's regions, including North-Eastern ones, where textile manufactures have been strongly present since Venetian time (Fontana, 2004), and lived world-known success stories, such as the Rossi, Marzotto, Stefanel, or Benetton (Belussi, 1992; Rovizzi, 1992; Tait, 1998; Fontana, 2005; Favero, 2012). Within this broadly adverse trend, there is, however, evidence of single firms having managed to re-organize their own business and develop innovative strategies within rentable niches (Bettiol, 2015). The paper aims at enhancing our understanding of the possibilities of reaction of small and medium enterprises (SMEs) operating in highly competitive markets combining analysis of empirical data and case study methods. Our main goal is to verify if and through which approaches small businesses can withstand unfavorable economic trends and compete successfully in global markets. The paper investigates, in particular, how handicrafts succeed in changing the 'traditional rules of the game' in their favour through marketing, product, and process reorganization. The research has focused on the fashion and clothing sector in Vicenza province because of its relevance in regional and national economy; its historical importance; its recent critical trends in terms of turnover, number of firms, and employees. The case studies of individual firms, on the other hand, have been selected because they represent clear examples of small family-run artisanal businesses successfully operating in complex environments. The reference period of the paper is 2000-2018, which overlaps with the economic stagnation following the European monetary union, the 2008 financial crisis, and the following restructuring of the world economy.

The study is divided into three parts. First of all, it provides a critical review of selected literature on the formation of the clothing and fashion industry in Vicenza province, of its development, of its strengths and weaknesses. Then we reconstruct, through statistical and empirical analysis, the sector's most recent trends, focusing on firms' strategies to counteract negative economic conditions. It concludes by explaining how SMEs can, within certain conditions, find successful strategies in the time of enduring crisis, when the markets are shrinking.

\section{Literature review}

The so-called 'fashion system' includes businesses producing clothing and accessories. It traditionally represents a core sector of the national economy in Italy (Paris, 2006; Merlo, 2011). Even nowadays, though significantly reduced in scope in comparison with the 1990s, it still holds a relevant position in Italian industrial production and international trade (Paris, 2006; Merlo, 2015). 
Researchers explain such results by stressing historical and culturally embedded entrepreneurial skills and by pointing out the ability of Italian firms to interpret and mould consumers' preferences (Scarpellini, 2019; Belfanti, 2015; Merlo, 2012). Scholars also highlight Italian firms' capacity to play successfully within global value chains, upgrade their position effectively, use the possibilities offered by collaboration with international brands and buyers, and promote collaboration at the district level (Dunford, 2006; Merlo, 2018; Bettiol, 2017). The latter aspect emerges especially strong among little enterprises operating within close territorial boundaries, such as the textile districts located in Veneto (Bettinelli, 2016).

Studies on Veneto's and Vicenza's 'fashion system' focused first of all on its century-long history; on the role of industrial districts and clusters; and on its resilience to market transformation and crisis. The sector experienced a remarkable development from the late Middle Ages, when home spinning and weaving where inserted in highly competitive, proto-industrial networks (Riello, 2013; Caracausi, 2017. From the early $19^{\text {th }}$ century it was deeply industrialized, and major factories, often integrated into company towns in the pre-alpine area, transformed economy, landscape and social life (Fontana, 2004; Roverato, 2004, Leoni, 2017). The process, however, didn't substitute home-based production. Industrial plants and independent spinners and weavers established complementary relations (Fontana, 2009; Celetti, 2015). Similarly, industrial and agricultural work coexisted at family level within pluri-activity frameworks, adding resilience to local societies and competitiveness to major companies (Fontana, 2005; Celetti, 2015). In that period there emerged features that still characterize the regional economy and landscape, such as the so-called 'diffused industrialization', shops and cultivated fields, rural and industrial areas following each other without solution of continuity (Ferrario, 2013; Belfanti, 2013; Celetti, 2019). From the 1960s, the 'subcontracting revolution' increased dramatically the number of little factories, large firms externalizing labor intensive production phases to focus on conception, design, marketing, and commercialization (Belussi, 1992; Ketelhöhn, 1993; Favero, 2012). Downscaling and reorganization processes induced, as we stressed, the emergence of numerous small subcontractors, which, by the 1980s, contributed to the formation of internationally competitive clusters, where shops specialized in different parts of the production chain, built synergies with those working in related sectors (e.g. machine building) and with larger companies controlling the strategic parts of the value chain and promoting international brands (Coro', 1999; Mistri, 2009).

There is vast research literature on cluster and industrial districts ${ }^{1}$ (Cainelli, 2008; Bettiol, 2019). Of particular interest for our research are the studies on the role of the territory as a complex asset for competitiveness (Lacquement, 2016) as well as on the latest transformation of industrial districts in the fast changing and globalizing economy (Brioschi, 2002; Mariotti, 2020). Studies highlight the financial and managerial limits of the 'small-scale' factories (Whitford, 2001); their resilience to crisis (Coro, 2010; Busato, 2011); and the effects of delocalization and offshoring practices on districts and clusters (Tattara, 2010; Coro', 2013). For our research particularly interesting are the studies on the reaction capacities of clusters, and, generally speaking, of SMEs operating in linked sectors. These studies stress the role of territory in enhancing resilience, on the one hand, and in building viable positions within global commodity chains, on the other (Coro', 2007; Volpe, 2012; Camagni, 2013; Buciuni, 2018; Barzotto, 2018). In that context, territory assumes a central role as a source of material and immaterial assets, including the exploitation of the brand "Made in Italy" as a world-wide recognized insurance of upper class design, aesthetic and quality (Lees-Maffei, 2004; Gilmore, 2007; Fontana, 2010; Balland, 2015; Celetti, 2019b). This study draws in particular from these studies and highlights how small handicrafts operating in the sector that is particularly exposed to global competition can reach excellence, namely by creating unique quality and using territorially-based competitive advantages.

\section{Methodology}

Methodologically, the work unites quantitative analysis of statistical data with qualitative, empirical observations gained from interviews and from field research of production processes. The combination of these approaches gives us insights into the strategies that small handicrafts follow for building their success stories in declining and turbulent markets.

${ }^{1}$ On differences between the two concepts cfr. Porter, 2009; Ortega-Colomer, 2016. 
We used statistical data to reconstruct the sector's trends of textile, clothing, and leather production at the provincial level ${ }^{2}$. The data have been obtained from Istat ${ }^{3}, \mathrm{ICE}^{4}$, and UnionCamere-InfoCamere ${ }^{5}$ official publications.

The four case studies we discuss further have been selected by the joint team of Padua University and Confartigianato Vicenza ${ }^{6}$ among the 529 clothing and fashion firms that are members

2 These activities are classified within Istat - Ateco (economic activity) classification numbers 13, 14, and 15 (2007), excluding 15.11 (leather and fur preparation).

${ }^{3}$ Italian Statistical Institute (www.istat.it).

${ }^{4}$ Italian Institute for Foreign Trade (www.ice.it).

${ }^{5}$ Information and Statistical Service of Italian Chamber of Trade (www.unioncamere.gov.it > infocamere).

6 "Confartigianato Vicenza" is an association of small and medium handicraft firms operating in Vicenza (https://www. confartigianatovicenza.it). of the above-mentioned Association on the basis of four parameters: dimension; production's specialization; location; and competitive success in the global market (Tables 1 and 2). The field research has been realized by working with the interviewees and entailed visits to the shops; reconstruction of the business process; acquisition of the 'grey material', such as brochures, photographs, newspaper articles; and formal, recorded interviews with companies' founders, owners, directors, and selected personnel. The interviews were based on questionnaires divided into five parts (the firm's history and recent development; business models; strengths; critical issues; and prospects) with a focus on the relevance of the firms' dimension, the value of the 'made in Italy' brand, and the role of the territory' in the time of globalization.

Table 1

Case Studies Main characteristics

\begin{tabular}{|c|c|c|c|c|}
\hline & Arca di Noe' (A) & Vicenza Mode (V) & La Pony Confezioni (P) & Four Horses (F) \\
\hline $\begin{array}{l}\text { Denomination, } \\
\text { Address, } \\
\text { Web-site }\end{array}$ & $\begin{array}{l}\text { L'ARCA DI NOE' SRL - } \\
\text { UNIPERSONALE } \\
\text { Via Rambolina 31/ } \\
\text { B - 36061 Bassano Del } \\
\text { Grappa (Vicenza -Italy) - } \\
\text { no web site }\end{array}$ & $\begin{array}{l}\text { VICENZA MODE } \\
\text { SRL - Via delle Industrie, } \\
78,36050 \text { Cartigliano } \\
\text { (Vicenza Itally) - https:// } \\
\text { www.vicenzamode.com }\end{array}$ & $\begin{array}{l}\text { LA PONY CONFEZI- } \\
\text { ONI SNC - via della } \\
\text { Cooperazione, } 1936025 \\
\text { Noventa Vicentina (Vi- } \\
\text { cenza - Italy) } \\
\text { https://www.lapony.it/ }\end{array}$ & $\begin{array}{l}\text { For Horses SRL - Via J.F. } \\
\text { Kennedy } 59 \text { - San Vito di } \\
\text { Leg. (VI - Italy) } \\
\text { https://forhorses.it/ }\end{array}$ \\
\hline Branch & $\begin{array}{l}\text { Outwear, in particular } \\
\text { using technical fabrics } \\
\text { and heating tape technol- } \\
\text { ogies for brands working } \\
\text { in high quality, ready to } \\
\text { wear segments (designer/ } \\
\text { diffusion) }\end{array}$ & $\begin{array}{l}\text { Knitwear manufacturing } \\
\text { for brands working in } \\
\text { high quality, ready to } \\
\text { wear segments (designer/ } \\
\text { diffusion) }\end{array}$ & $\begin{array}{l}\text { Production of men's and } \\
\text { women's trousers }\end{array}$ & $\begin{array}{l}\text { Production of equestrian } \\
\text { outwear and accessories }\end{array}$ \\
\hline $\begin{array}{l}\text { Years of } \\
\text { activity }\end{array}$ & 34 & $\begin{array}{l}30 \text { (following the trans- } \\
\text { formation of the preced- } \\
\text { ing family business in the } \\
\text { same sector created in } \\
1970 \text { ) }\end{array}$ & 39 (founded in 1980) & 18 (founded in 2002) \\
\hline Employees & $\begin{array}{l}26 \text { part-time employees } \\
(20 \text { hours a week })\end{array}$ & 60 full-time employees & 30 full-time employees & 15 \\
\hline $\begin{array}{l}\text { Production } \\
\text { process }\end{array}$ & $\begin{array}{l}\text { Cutting, tailoring, wash- } \\
\text { ing, ironing, testing, and } \\
\text { shipping }\end{array}$ & $\begin{array}{l}\text { Choice of yarn, weaving, } \\
\text { cutting, tailoring, wash- } \\
\text { ing, ironing, testing, and } \\
\text { shipping }\end{array}$ & $\begin{array}{l}\text { Cutting, tailoring, wash- } \\
\text { ing, ironing, testing, and } \\
\text { shipping. The firm also } \\
\text { offers projecting and } \\
\text { testing services }\end{array}$ & $\begin{array}{l}\text { Cutting, tailoring, wash- } \\
\text { ing, ironing, testing, and } \\
\text { shipping }\end{array}$ \\
\hline $\begin{array}{l}\text { Markets and } \\
\text { clients }\end{array}$ & $\begin{array}{l}\text { Final product for major } \\
\text { brands of the interna- } \\
\text { tional fashion system } \\
\text { working in high quality, } \\
\text { ready to wear segments } \\
\text { (designer/diffusion) }\end{array}$ & $\begin{array}{l}\text { Final product for major } \\
\text { brands of the interna- } \\
\text { tional fashion system } \\
\text { working in high quality, } \\
\text { ready to wear segments } \\
\text { (designer/diffusion) }\end{array}$ & $\begin{array}{l}\text { Final product for major } \\
\text { brands of the interna- } \\
\text { tional fashion system } \\
\text { working in high quality, } \\
\text { ready to wear segments } \\
\text { (designer/diffusion) }\end{array}$ & $\begin{array}{l}\text { Final product sold world- } \\
\text { wide under its own brand } \\
\text { to buyers, distributors, } \\
\text { shops, and private clients } \\
\text { (riders), also on-line }\end{array}$ \\
\hline
\end{tabular}

Source: Interviews to Roberto Sartori (Arca di Noe' SRL), interviewed by David Celetti, September 20th, 2018 at the firm's offices, Via Rambolina 31/B, Bassano Del Grappa (Vicenza, IT): Riccardo Garbosso (Vicenza Mode SRL), interviewed by David Celetti, September 20th, 2018 at the firm's offices, Via delle Industrie 78, Cartigliano (Vicenza, IT); Riccardo Barbato (La Poni Confezioni SNC), interviewed by David Celetti, September 20th, 2018 at the firm's offices, via della Cooperazione, 19, Noventa Vicentina (Vicenza, IT); Andrea Piovan (For Horses SRL), interviewed by David Celetti, March 14th, 2019 at the firm's offices, Via Kennedy 59, San Vito di Leguzzano (Vicenza, IT). 


\section{Table 2}

Case studies results (A: Arca di Noe' - V: Vicenza Mode - P: La Pony Confezioni - F: For Horses).

\begin{tabular}{|c|c|c|c|c|}
\hline $\begin{array}{c}\text { Origins } \\
\text { and Development }\end{array}$ & Business Model & Strengths & Critical Issues & Prospects \\
\hline $\begin{array}{l}\text { Family business di- } \\
\text { rectly managed by the } \\
\text { owner }(A, P, V, F)\end{array}$ & $\begin{array}{l}\text { Subcontractor furnishes } \\
\text { the final product and } \\
\text { operates in all the phases } \\
\text { of the production chain } \\
\text { (V) or from cutting } \\
\text { downwards (A, P). } \\
\text { The business process } \\
\text { includes projecting and } \\
\text { prototyping (A, P, V, F) } \\
\text { The firm operates with } \\
\text { its own brand, selling } \\
\text { directly to distributors or } \\
\text { final clients (F) }\end{array}$ & $\begin{array}{l}\text { Extremely high quality, } \\
\text { versatility and flexibili- } \\
\text { ty }(\mathrm{A}, \mathrm{P}, \mathrm{V}) \\
\text { Technical competenc- } \\
\text { es for professional } \\
\text { riding necessities with } \\
\text { attention to style and } \\
\text { fashion (F) }\end{array}$ & $\begin{array}{l}\text { Difficulty in finding } \\
\text { highly qualified per- } \\
\text { sonnel at all levels (A, } \\
\mathrm{P}, \mathrm{V}, \mathrm{F})\end{array}$ & $\begin{array}{l}\text { Building continu- } \\
\text { ously in knowledge, } \\
\text { skills, and know-how } \\
\text { as instruments for } \\
\text { enhancing quality and } \\
\text { service (A, P, V, F) }\end{array}$ \\
\hline $\begin{array}{l}\text { The owner is: } \\
\text { A. Former manager of a } \\
\text { big textile company }(\mathrm{A}) \\
\text { B. Son of the founder } \\
\text { with technical experi- } \\
\text { ence in the sector }(\mathrm{P}, \mathrm{V}) \text {. } \\
\text { C. A former technician } \\
\text { in a chemical company } \\
\text { and a former design- } \\
\text { er of classical dance } \\
\text { outwear }\end{array}$ & $\begin{array}{l}\text { Offer includes counsel- } \\
\text { ing services to current } \\
\text { or potential clients (A, } \\
\text { P, V, F) }\end{array}$ & $\begin{array}{l}\text { Original production } \\
\text { process management } \\
\text { - Innovative organiza- } \\
\text { tion model based on } \\
\text { remote team work with } \\
\text { the clients (V, P) } \\
\text { - Innovative organi- } \\
\text { zation model using } \\
\text { part-time to enhance } \\
\text { flexibility (A) } \\
\text { - Coexistence of high } \\
\text { technology, technical } \\
\text { innovation and handi- } \\
\text { craft approaches (F) }\end{array}$ & $\begin{array}{l}\text { Keeping the perceived } \\
\text { value of the 'Made } \\
\text { in Italy' brand with } \\
\text { enhanced protection of } \\
\text { the brand }(A, P, V, F)\end{array}$ & $\begin{array}{l}\text { Process and product } \\
\text { innovation, uniting } \\
\text { tradition and technol- } \\
\text { ogy }(\mathrm{A}, \mathrm{P}, \mathrm{V}, \mathrm{F})\end{array}$ \\
\hline $\begin{array}{l}\text { The firms have been } \\
\text { constantly moved } \\
\text { towards the upper mar- } \\
\text { ket's segments and are } \\
\text { now positioned in the } \\
\text { luxury fashion segment } \\
(\mathrm{A}, \mathrm{P}, \mathrm{V})\end{array}$ & $\begin{array}{l}\text { Product specialization } \\
\text { on knitwear manufac- } \\
\text { turing (V), trousers (P), } \\
\text { technical outwear (A), } \\
\text { equestrian outwear (F) }\end{array}$ & $\begin{array}{l}\text { Highly qualified } \\
\text { personnel in measur } \\
\text { to work manually and } \\
\text { exploit at the same time } \\
\text { the highest technology } \\
(\text { A, P, V, F) }\end{array}$ & $\begin{array}{l}\text { Keeping enough firms } \\
\text { working in the terri- } \\
\text { tory and building up } \\
\text { more effective policies } \\
\text { for maintaining the } \\
\text { vitality' of the clothing } \\
\text { and fashion industrial } \\
\text { district }(\mathrm{A}, \mathrm{P}, \mathrm{V}, \mathrm{F})\end{array}$ & $\begin{array}{l}\text { Focusing on luxury } \\
\text { brands for limiting } \\
\text { price competition (A, } \\
\text { P, V) } \\
\text { Enhancing its visibil- } \\
\text { ity at world level in } \\
\text { the niche market also } \\
\text { exploiting IT (F) }\end{array}$ \\
\hline \multirow[t]{2}{*}{$\begin{array}{l}\text { The firms have been } \\
\text { operating in the niche } \\
\text { segment since the very } \\
\text { beginning }(F)\end{array}$} & \begin{tabular}{l|} 
Focus on the highest \\
market levels. Clients are \\
international renowned \\
luxury fashion brands \\
(A, P, V) \\
Clients are professional \\
and high-level amateur \\
riders served directly \\
or through distributors \\
worldwide, the domestic \\
market remaining mar- \\
ginal (F)
\end{tabular} & $\begin{array}{l}\text { Upper-class services, } \\
\text { including innovation, } \\
\text { and problem-solving, } \\
\text { which helps to build } \\
\text { long-term relations } \\
\text { with clients }(\mathrm{A}, \mathrm{P}, \mathrm{V}, \mathrm{F})\end{array}$ & $\begin{array}{l}\text { Keeping very close long } \\
\text {-term relations with } \\
\text { fashion luxury brands, } \\
\text { which are linked not } \\
\text { only to the firm's per- } \\
\text { formance, but also to } \\
\text { the values 'embedded' } \\
\text { in the territory (A, P, V) }\end{array}$ & $\begin{array}{l}\text { Communicate effec- } \\
\text { tively the tangible and } \\
\text { intangible (cultural) } \\
\text { values of the "made } \\
\text { in Italy" brand and } \\
\text { of the regional textile } \\
\text { districts (A, P, V, F) }\end{array}$ \\
\hline & $\begin{array}{l}\text { Strong links with French } \\
\text { luxury brands: show- } \\
\text { room in Paris, and valu- } \\
\text { able products' archive } \\
\text { (V) } \\
\text { Strong links to the } \\
\text { American market: office } \\
\text { in Miami (F) }\end{array}$ & $\begin{array}{l}\text { The production is total- } \\
\text { ly under the 'Made in } \\
\text { Veneto' brand, exploit- } \\
\text { ing the territory as a } \\
\text { competitive advantage } \\
(\mathrm{A}, \mathrm{P}, \mathrm{V}, \mathrm{F})\end{array}$ & & \\
\hline
\end{tabular}

Source: Interview with Roberto Sartori (Arca di Noe' SRL) conducted by David Celetti, September 20th, 2018 at the firm's office, Via Rambolina 31/B, Bassano Del Grappa (Vicenza, IT): interview with Riccardo Garbosso (Vicenza Mode SRL) conducted by David Celetti, September 20th, 2018 at the firm's office, Via delle Industrie 78, Cartigliano (Vicenza, IT); interview with Riccardo Barbato (La Poni Confezioni SNC) conducted by David Celetti, September 20th, 2018 at the firm's office, via della Cooperazione, 19, Noventa Vicentina (Vicenza, IT); interview with Andrea Piovan (For Horses SRL) conducted by David Celetti, March $14^{\text {th }}, 2019$ at the firm's office, Via Kennedy 59, San Vito di Leguzzano (Vicenza, IT). 


\section{Results}

Vicenza's 'fashion system' (textile, clothing, leather) manifests evident degrees of territorial specialization within one of the most industrialized Italian provinces (Table 3). This aspect is clearly highlighted both by ISTAT analysis of the sector's districts ${ }^{7}$ and by that of BancaIntesa (BancaIntesa 2018, 126, 205). Firms of the fashion sector are mainly concentrated in the South-Eastern part of the territory (municipalities of Barbarano and Noventa) and in the 'traditional textile centers' of the medium and northern communes, such as those of Thiene, Bassano, and Marostica. Similar results are obtained applying the 'economic specialization index' (Palan, 2010) to the handicraft shops operating in single municipalities. In 2017, the index showed concentration rates of 0.141-0.300 (7 municipalities) and 0.301-1.000 (2 municipalities), namely in the South-Eastern and Central areas of Vicenza province (Figure 1). However, no municipality has rates higher than 1.000 , which theoretically correspond to the presence of an industrial district. This configuration is the consequence of both the 1990s transformation, marked by diffused delocalization, and of the crisis of the two last decades, which, in the way similar to the national trends ${ }^{8}$ (Banca Intesa, 2018) heavily influenced the territorial economic structure, reducing the number of active handicrafts and therefore lowering the concentration index itself (Figure 1).

ISTAT 2001. 8o Censimento generale dell'industria e dei servizi. Distretti indusrtiali e sistemi locali del lavoro. (53-95) (https://www.istat.it/it/files/2011/01/Volume Distretti1.pdf); ISTAT 2011. 9o Censimento dell'industria e dei servizi e Censimento delle istituzioni non profit. I distretti industriali. (42-50)

${ }^{8}$ ISTAT 2011. 9o Censimento dell'industria e dei servizi e Censimento delle istituzioni non profit. I distretti industriali. (25); ISTAT 2018. Rapporto Annuale 2018. La situazione del Paese (57-72)

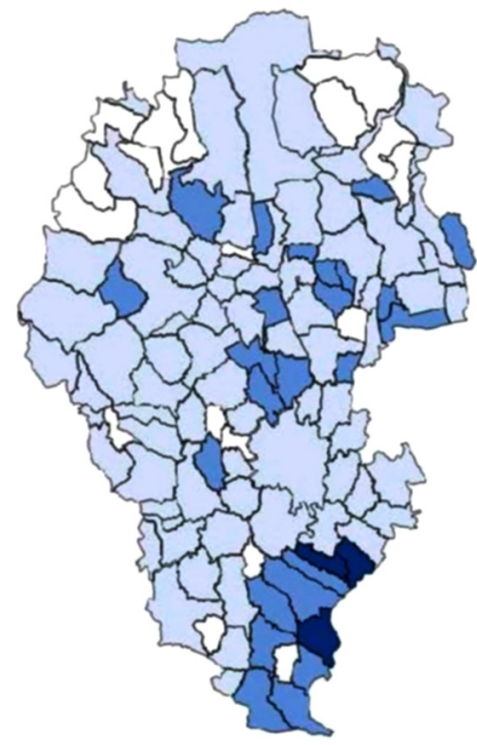

Figure 1. Concentration index of textile and clothing handicraft in Vicenza (2017 - Dark Blue 0.301-1; Blue 0.141-0.3: Light Blue less than 0.140; white 0)

Source: Confartigianato Vicenza - Elaborazione Flash $04 / 03 / 2020$

However, in contiguous territories we still notice the presence of numerous firms operating in different parts of the production chain. Proximity represents an important competitive advantage at provincial level. It enhances the sector's capacity to respond positively to the demand of flexibility, quality, and 'customization' of the final buyers, optimizing production processes through inter-company cooperation. It fosters innovation, mutual learning, and knowledge spillover. It increases resilience to any sudden variations of demand. Areas with higher concentration indexes, therefore, better react to crisis and faster develop new business approaches (Balland, 2015). This aspect appears all the more as a strategic asset if we take into account that the main business model

Gross Domestic Product (mln euro) of Vicenza Province, Veneto Region and Italy

\begin{tabular}{|c|c|c|c|c|c|c|c|c|c|c|c|c|c|}
\hline GDP/Year & 2003 & 2004 & 2005 & 2006 & 2007 & 2008 & 2009 & 2010 & 2011 & 2012 & 2013 & 2014 & 2015 \\
\hline VICENZA & 21971 & 23590 & 24018 & 24219 & 25470 & 25113 & 24464 & 25125 & 26157 & 25883 & 26302 & 26603 & 27125 \\
\hline VENETO & 124288 & 130716 & 133488 & 140576 & 147009 & 145923 & 142364 & 145053 & 149642 & 147215 & 147317 & 149888 & 151791 \\
\hline \begin{tabular}{|l|} 
Perc. Vi- \\
cenza GDP \\
vs Veneto's \\
GDP \\
\end{tabular} & 17,68 & 18,05 & 17,99 & 17,23 & 17,33 & 17,21 & 17,18 & 17,32 & 17,48 & 17,58 & 17,85 & 17,75 & 17,87 \\
\hline ITALIA & 1335354 & 1390539 & 1436379 & 1493031 & 1554199 & 1575144 & 1573655 & 1604515 & 1637463 & 1613265 & 1604599 & 1621827 & 1645439 \\
\hline $\begin{array}{l}\text { Perc. Vene- } \\
\text { to GDP vs } \\
\text { Italy's GDP }\end{array}$ & 9,31 & 9,40 & 9,29 & 9,42 & 9,46 & 9,26 & 9,05 & 9,04 & 9,14 & 9,13 & 9,18 & 9,24 & 9,22 \\
\hline
\end{tabular}

Sources: Author's own calculations by using the data from Vicenza Chamber of Trade (https://www.vi.camcom.it/it/servizi/ statistica-e-studi/tabelle-statistiche-dati-settoriali.html) 
of Vicenza's fashion system is 'contract manufacturer'. The option is one of the consequences of the outsourcing processes of major companies in the 1960s and 1970s. Traditionally, artisans produce parts of the final product according to the quality standards set by the client. Their focus is therefore on the production process, which only rarely includes projecting and development (design, prototype, collection, etc.). However, in the recent years, the latter is becoming a part of the "upgrading" strategies of successful handicrafts. In any case, proximity and cooperation are essential strategic tools for subcontracting firms (Bettiol, 2017; Magnani, 2019).

As we have seen, the relatively low concentration index also mirrors the sector's crisis and transformations that diminished the number of active firms. Since the late 1980s, when it reached its heights, clothing industry has endured significant changes under the pressure of fierce international competition on the part of developing countries (Figure 2). At provincial level, active handicraft firms went from 1,315 in 2009 to 1,113 in 2018, showing a reduction of more than $15 \%$, which reflects regional $(-16,12)$ and national $(-15.42)$ trends (Figures 3 and 4). Although it is difficult to make comparisons throughout the whole period due to the modification in the classification of sectors in 2008, figures show that the reduction in the number of firms has been an ongoing tendency since the beginning of the $21^{\text {st }}$ century, suggesting structural rather than conjuncture trends (Table 4, Figures 5, 6 and 7). Similarly, the evolution of handicrafts' labor levels underwent a negative evolution (Figure 8 ) whereas the number of workers per production unit remained stable (7,29 in 2012 and 7,25 in 2028). This might suggest the limits of increasing productivity through the process of reorganization and/or technologic innovation in the sector where labor remains a central asset. At national level, for example, only 11.9 per cent of fashion firms operating in industrial districts show excellent use of IT, whereas the average industry level reaches 16.6 (Banca Intesa, 2018, 134).

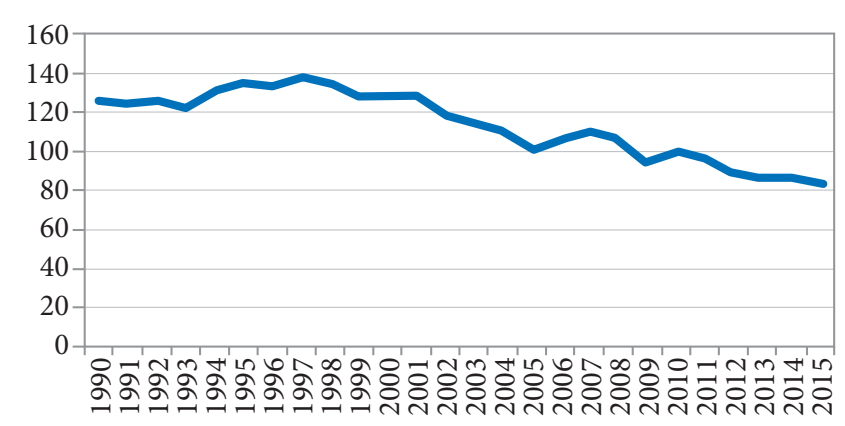

Figure 2. Total production index of Italy's clothing and fashion industry $(2004=100)$. Source: http://seriestoriche.istat.it/

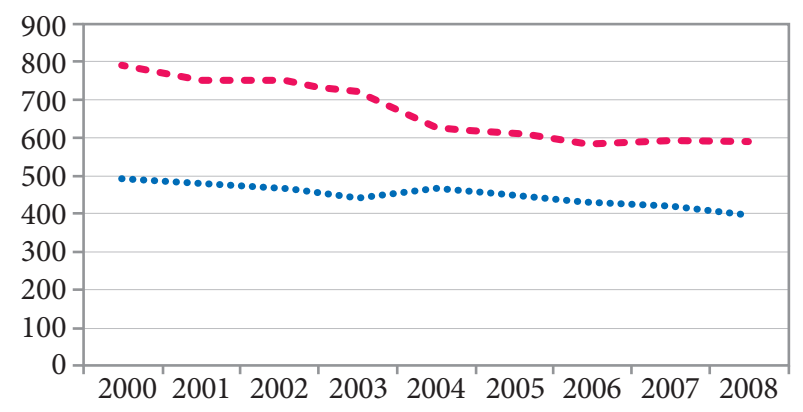

Figure 3. Number of active artisan companies in the clothing (red) and textile (blue) sectors

Sources: the author's own calculations based on Infocamere Data (Economic Sectors DB17: textile industries; DB18 Clothing Production including furs - https://www.infocamere.it/statistiche/-/most viewed assets/zaAtS5lJ6QVI/ content/cerca-tabelle-movimprese?inheritRedirect=false)

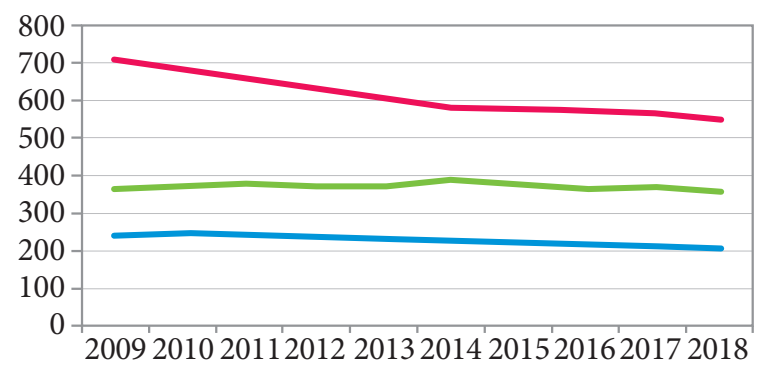

Figure 4. Number of active artisan companies in the clothing (red), leather and textile (blue) sectors Source: the author's own calculations based on Infocamere data (Economic Sectors B13: textile industries; B14 Clothing Production; B 15: Leather Goods Production - https:// www.infocamere.it/statistiche/-/most viewed assets/zaAtS51J6QVI/content/cerca-tabelle-movimprese?inheritRedi$\underline{\text { rect=false) }}$

Clothing and fashion firms. Vicenza Province and Italy

\begin{tabular}{|l|r|r|r|r|r|r|r|}
\hline \multicolumn{1}{|c|}{ Year } & \multicolumn{1}{|c|}{$\mathbf{2 0 1 2}$} & \multicolumn{1}{c|}{$\mathbf{2 0 1 3}$} & $\mathbf{2 0 1 4}$ & $\mathbf{2 ~ 0 1 5}$ & \multicolumn{1}{c|}{$\mathbf{2 0 1 6}$} & $\mathbf{2 0 1 7}$ & \multicolumn{2}{c|}{$\mathbf{2 0 1 8}$} \\
\hline Handicrafts firms (Vicenza Province) & 905 & 870 & 839 & 834 & 831 & 814 & 786 \\
\hline Total Firms (Vicenza Province) & 1709 & 1663 & 1634 & 1645 & 1717 & 1617 & 1587 \\
\hline Handicrafts firms (Italy) & 48431 & 47272 & 46290 & 45617 & 44782 & 44004 & 43092 \\
\hline Total Firms (Italy) & 93973 & 91682 & 89926 & 89030 & 87721 & 86403 & 85177 \\
\hline
\end{tabular}

Source: ISTAT (http://www.coeweb.istat.it/ April 19 th 2020 ), and the author's calculations 


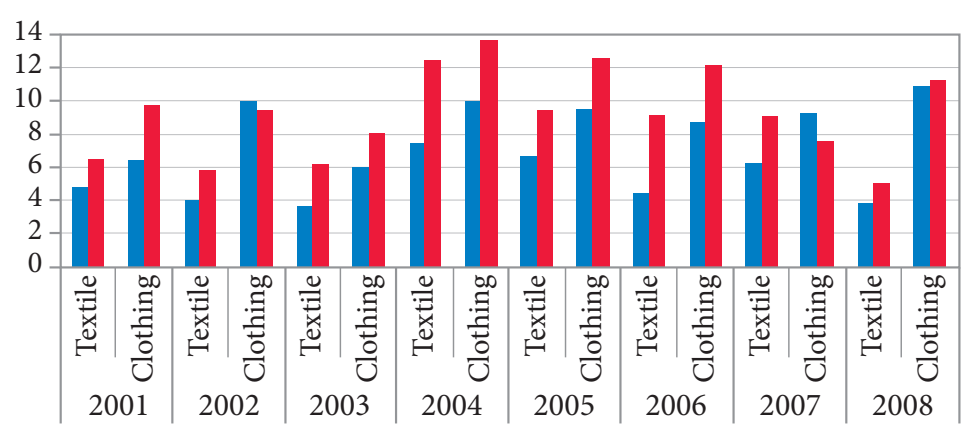

Figure 5. Indexes of natality (blue) and mortality (red) textile and clothing artisanal firms

Source: the author's own calculations on Infocamere data (Economic Sectors DB17: textile industries; DB18 Clothing Production including furs - https://www.infocamere.it/statistiche/-/most viewed assets/zaAtS51J6QVI/content/cerca-tabelle-movimprese?inheritRedirect=false)

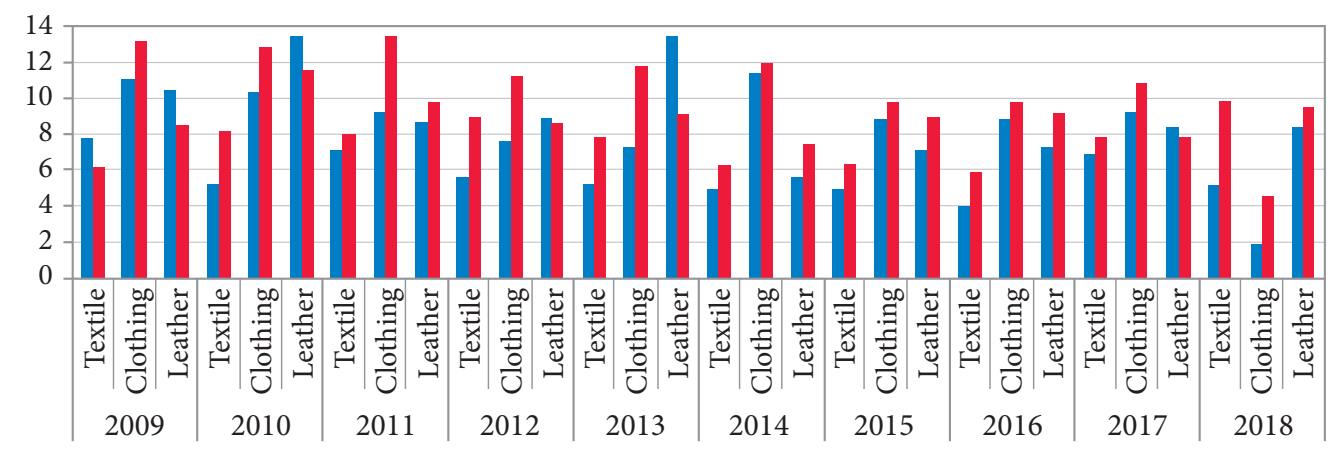

Figure 6. Indexes of natality (blue) and mortality (red). Province of Vicenza. Fashion System Artisanal Firms Source: the author's own calculations on Infocamere data (Economic Sectors B13: textile industries; B14 Clothing Production; B 15: Leather Goods Production - https://www.infocamere.it/statistiche/-/most viewed assets/zaAtS5IJ6QVI/content/cerca-tabelle-movimprese?inheritRedirect=false)

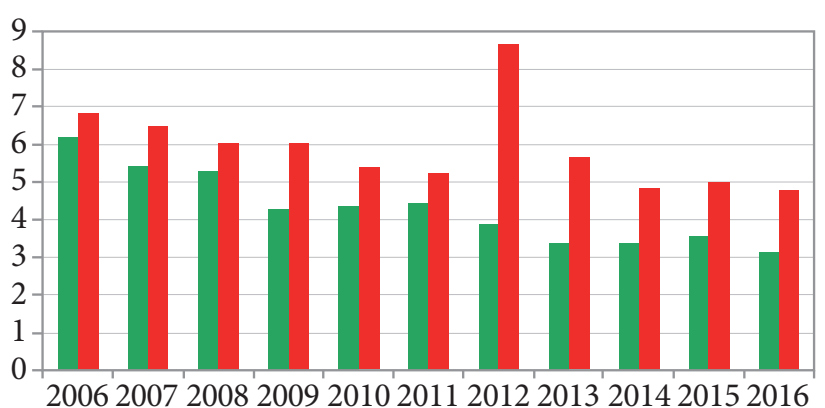

Figure 7. Indexes of natality (green) and mortality (red). Province of Vicenza. All industrial sectors Source: the author's own calculations based on Infocamere data - https://www.infocamere.it/statistiche/-/most viewed assets/zaAtS51J6QVI/content/cerca-tabelle-movimprese?inheritRedirect=false)

Vicenza's 'fashion system' shows a strong orientation to the foreign markets, exports having a relevant share of turnover (Tables 5,6 and 7) . The $^{9}$ most important clients are European, in particular Germany, France and the UK. Asia, however, is growing much faster as a result of rampant Chinese and, to a lesser extent, Indian demand.

\footnotetext{
${ }^{9}$ Rapporto ICE 2017/2018. L'Italia nell'economia internazionale. Roma: Marchesi Grafiche Editoriali (22-24, 38, 45-54).
}

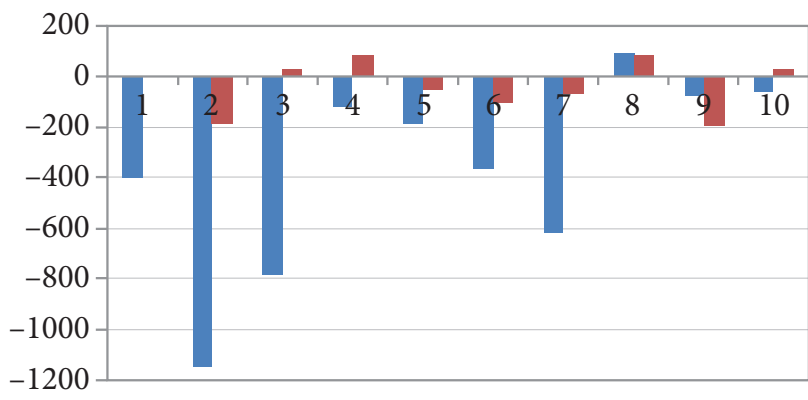

Figure 8. Employees (blue) and variation (red).

Province of Vicenza. Fashion System Artisanal Firms

Sources: the author's own calculations based on Ufficio Studi Confartigianato data (Elaborazione Flash 04.03.2020)

The last two countries, though still considered 'emerging', nevertheless, increasingly generate demand for high quality, luxury fashion products. The importance of Western countries, in particular France, is also linked to the focus of Italian fashion industry on upper class production largely controlled by French luxury brands. Conversely, it highlights the diminishing numbers of firms working in medium and low segments, exposed 
to price competition of emerging countries. The latter suggests that upgrading towards higher segments represents the best possible option for staying in the market (Table 5 and 7).

Table 5

\section{Fashion system (including leather). \\ Share in the International Trade of the Province of Vicenza}

\begin{tabular}{|c|c|c|c|c|c|}
\hline \multicolumn{3}{|c|}{ Imports } & \multicolumn{3}{c|}{$\begin{array}{c}\text { Imports } \\
\text { (\% on total imports) }\end{array}$} \\
\hline 2013 & 2014 & 2015 & 2013 & 2014 & 2015 \\
\hline 1886552 & 2030996 & 2143061 & $22,3 \%$ & $22,9 \%$ & $24,0 \%$ \\
\hline \multicolumn{3}{|c|}{ Exports } & \multicolumn{3}{c|}{$\begin{array}{c}\text { Exports } \\
\text { (\% on total imports) }\end{array}$} \\
\hline 2013 & 2014 & 2015 & 2013 & 2014 & 2015 \\
\hline 3857124 & 4102129 & 4358586 & $24,7 \%$ & $25,3 \%$ & $25,5 \%$ \\
\hline
\end{tabular}

Sources: Author's Elaboration on Data from Vicenza Chamber of Trade (https://www.vi.camcom.it/it/servizi/statistica-e-studi/tabelle-statistiche-dati-settoriali.html)
Empirical research on case studies confirms the evidence shown by statistical analysis, adding, however, insights into how handicraft reached top positions through innovative interpretation of their business models ${ }^{10}$.

${ }^{10}$ Empirical analysis in mainly based on the interview of Roberto Sartori (Arca di Noe' SRL) conducted by David Celetti, September 20th, 2018 at the firm's office, Via Rambolina 31/B, Bassano Del Grappa (Vicenza, IT); the interview of Riccardo Garbosso (Vicenza Mode SRL) conducted by David Celetti, September 20th, 2018 at the firm's office, Via delle Industrie 78, Cartigliano (Vicenza, IT); the interview of Riccardo Barbato (La Poni Confezioni SNC) conducted by David Celetti, September 20th, 2018 at the firm's office, via della Cooperazione, 19, Noventa Vicentina (Vicenza, IT); interview with Andrea Piovan (For Horses SRL) conducted by David Celetti, March 14th, 2019 at the firm's office, Via Kennedy 59, San Vito di Leguzzano (Vicenza, IT). The analysis also uses the data from the websites: https://www.vicenzamode.com/; https://www.lapony.it/; https://forhorses.it/.

Table 6

Italian Exports

\begin{tabular}{|c|c|c|c|c|c|c|}
\hline \multirow{2}{*}{ 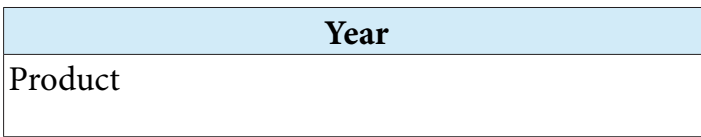 } & \multicolumn{2}{|c|}{2019} & \multicolumn{2}{|c|}{2020} & \multicolumn{2}{|c|}{ Var. \% } \\
\hline & $\begin{array}{l}\text { tons } \\
(1000)\end{array}$ & $\begin{array}{c}\text { Euro } \\
(1,000,000)\end{array}$ & $\begin{array}{l}\text { tons } \\
(1000)\end{array}$ & $\begin{array}{c}\text { Euro } \\
(1,000,000)\end{array}$ & $\begin{array}{l}\text { Difference } \\
\quad(\%)\end{array}$ & $\begin{array}{l}\text { Difference } \\
(\%)\end{array}$ \\
\hline Pharmaceutical & 2376 & 26 & 2429 & 25 & 2,2 & $-5,1$ \\
\hline Automotive & 1400 & 121 & 1463 & 114 & 4,5 & $-6,4$ \\
\hline Oil products & 866 & 1944 & 1081 & 2403 & 24,9 & 23,6 \\
\hline Components and accessories for autonotive & 1071 & 156 & 1060 & 143 & $-1,1$ & $-7,9$ \\
\hline Shoes & 896 & 17 & 906 & 16 & 1,2 & $-4,5$ \\
\hline Cloths and accessories & 820 & 20 & 853 & 22 & 4,0 & 12,6 \\
\hline Clothing accessories & 781 & 5 & 821 & 5 & 5,1 & 7,2 \\
\hline $\begin{array}{l}\text { Ship's and aircraft's stores and supplies, returned } \\
\text { national goods, miscellaneous goods }\end{array}$ & 702 & 332 & 711 & 273 & 1,3 & $-17,8$ \\
\hline Precious metals including semi-finished goods & 388 & .. & 705 &.. & 81,5 & 40,1 \\
\hline Industrial machines & 696 & 32 & 695 & 29 & $-0,1$ & $-9,2$ \\
\hline Others & 25742 & 8980 & 25829 & 8694 & 0,3 & $-3,2$ \\
\hline total & 35738 & 11632 & 36553 & & 2,3 & 0,8 \\
\hline \multicolumn{7}{|c|}{ EXPORT'S COMPOSITION } \\
\hline Pharmaceutical & 6,6 & 0,2 & 6,6 & 0,2 & & \\
\hline Automotive & 3,9 & 1,0 & 4,0 & 1,0 & & \\
\hline Oil products & 2,4 & 16,7 & 3,0 & 20,5 & & \\
\hline Components and accessories for automotive & 3,0 & 1,3 & 2,9 & 1,2 & & \\
\hline Shoes & 2,5 & 0,1 & 2,5 & 0,1 & & \\
\hline Cloths and accessories & 2,3 & 0,2 & 2,3 & 0,2 & & \\
\hline Clothing accessories & 2,2 & .. & 2,2 & .. & & \\
\hline $\begin{array}{l}\text { Ship's and aircraft's stores and supplies, returned } \\
\text { national goods, miscellaneous goods }\end{array}$ & 2,0 & 2,9 & 1,9 & 2,3 & & \\
\hline Precious metals including semi-finished goods & 1,1 &.. & 1,9 & .. & & \\
\hline Industrial machines & 1,9 & 0,3 & 1,9 & 0,2 & & \\
\hline Others & 72,0 & 77,2 & 70,7 & 74,2 & & \\
\hline total & 100,0 & 100,0 & 100,0 & 100,0 & & \\
\hline
\end{tabular}

Source: ISTAT ( http://www.coeweb.istat.it/ April 19 ${ }^{\text {th }} 2020$ ), and the author's own calculations 


\section{Table 7}

Exports (1.000 Euro) of clothing and textile handicrafts and clothing and textile industry. Province of Vicenza (2011-17)

\begin{tabular}{|l|r|r|r|r|r|r|r|}
\hline \multicolumn{1}{|c|}{ Sector/Year } & \multicolumn{1}{c|}{$\mathbf{2 0 1 1}$} & $\mathbf{2 0 1 2}$ & $\begin{array}{c}\text { Variation 2011-12 } \\
\text { (perc.) }\end{array}$ & $\mathbf{2 0 1 6}$ & $\mathbf{2 0 1 7}$ & $\begin{array}{c}\text { Variation 2016-17 } \\
\text { (perc.) }\end{array}$ & $\begin{array}{c}\text { Variation 2011-17 } \\
\text { (perc.) }\end{array}$ \\
\hline $\begin{array}{l}\text { Clothing (including } \\
\text { fur and Leather) }\end{array}$ & 1078,00 & 1165,00 & 9,10 & 1239,60 & 1227,30 & $-1,00$ & 13,85 \\
\hline Textiles & 464,00 & 435,00 & $-6,30$ & 528,50 & 541,90 & 2,50 & 16,79 \\
\hline Total Handicrafts & 6627,00 & 7014,00 & 5,80 & 7807,60 & 8134,50 & 4,20 & 22,75 \\
\hline Total manufactures & 14341,00 & 14807,00 & 3,20 & 16604,20 & 17536,40 & 5,60 & 22,28 \\
\hline
\end{tabular}

Source: the author's own calculations by using the data from Confartigianato Vicenza Elaborazione Flash 2011-2019

The four selected case studies (Tables 1 and 2) are family businesses with 15 years of history. Two of them (Vicenza Mode - V- and La Pony P) have already successfully experienced generational transition, whereas Four Horses (F) and Arca di Noe' (A) are still managed by founders and do not foresee, at the moment, any transfer of competences and duties to younger entrepreneurs. The origins of the business are strictly linked to technical competences and formal personal experiences in major fashion companies or in related sectors in three cases (A, P, F). Only the founder of $\mathrm{V}$ had no direct experience in the sector and started his business on the simple assumption that the booming demand of the early 1970s would create opportunities for new entrants. The 'second generation', which is currently at the head of $\mathrm{V}$ and $\mathrm{P}$, obtained higher education and practical hands-on experience before joining the business. This shows the relevance of personal experience and skills, which might be managerial as in the case of A and P, or linked to specific knowledge of product characteristics, as in the case of $\mathrm{F}$ (Table 2). We also found that in the time of expansion, the simple feeling of market might play a positive role in entrepreneurial decision-making. Moreover, in all the cases, family emerges as a relevant actor, bringing competences and work, but also supporting effective decision-making. This last aspect confirms another central characteristic of Vicenza's - and Veneto's - industrial system, which can still be considered 'family based' and 'family led'.

Each story highlights typical stages of development of Vicenza's fashion clusters. V found its origins in the demand boom of the 1970s in Veneto's knitwear production, largely pulled by the success of the brands like Benetton, Stefanel, and their subcontracting strategies. P was founded as a spill-over of Marzotto, when Valdagno-based company started outsourcing labor intensive pro- duction phases. A was also created through company restructuration. What in fact happened is that in the late 1980s, a manager and a group of workers from a struggling major firm, which had to lay off, personnel decided to start their own business. Both of these stories represent, though each in its own way, a successful reaction to market transformations.

$\mathrm{F}$ tells the story of its own. The business started in the early 2000s, when Vicenza's fashion system already suffered a structural crisis. The firm was established as a result of its founder's passion for professional riding and his need for technical outwear. From the very beginning, the firm focused on the specific market niche where it managed to combine the technical requirements for professional riders, exclusive textiles, aesthetics, and functionality. The uniqueness of F's product, and the specificity of the market allowed the firm to create a new brand serving distributors (buyers and retailers) but also delivering directly to professional riders.

$\mathrm{A}, \mathrm{V}$ and $\mathrm{P}$ entered the markets as contractors of major brands and still hold this position. $\mathrm{V}$ develops the whole production chain from yarn selection to ironing, testing, and shipping; $\mathrm{A}$ and $P$ receive the cloths from their clients, whereas $\mathrm{F}$ buys it directly. Having very specific requirements, $\mathrm{F}$ works together with producers of fabric, mainly located in the nearby territory, to conduct research and testing. All firms deliver the final product, ready to be used by the consumer. This last aspect is considered extremely relevant, because it means that these firms avoid 'hyper-specialization' (e.g. performing only one task as is the case with Benetton's contracts) and they can acquire competences and know-how, which, in turn, represents the basis for their further progress and consolidation in upper market niches. Quality, specialization on specific textiles, work procedures, outwear as well as the capacity to provide 
additional services, such as technical counseling, are also a way to attract buyers internationally and to expand potential markets.

All firms have built over time their own unique competences, which enable them to enrich the product with particular services. Clients value the company's providing counseling on fibers' technical and aesthetical characteristics, co-projecting new fabrics, and delivering final products. These activities, on the other hand, are not viewed as a 'generating income directly', but as an asset for ensuring customer loyalty; promoting higher results through team work at the early stages of projecting and prototyping; for acquiring new competences; testing new production methods; and for ensuring constant 'upgrading' along the value chain (A, V, P). Similarly, F co-generates outwear and accessories in cooperation with professional riders, who actively test them and suggest changes, and with cloth producers, who do not simply receive specific technical and aesthetic requirements from $F$, but participate in developing them. All the firms consider collaboration as an essential competitive advantage. Territory plays in this sense a relevant role as it enhances collaboration potential through personal networks and attracts international buyers.

Currently all the selected firms are solidly positioned in the highest market segments delivering to world best brands or selling, as F, through its own brand to high class clients. Though all firms are extremely open to international markets, they also have some specific orientations. V, for example, is oriented towards French luxury brands. It opened its own showroom in Central Paris to attract firstclass clients as well as to comply to what is seen as a 'must' in the luxury fashion world. The reasons why the firm decided to go for the 'French option' are explained by the world fame of Parisian brands and by the stability in business relationships, financial reliability, cooperative approaches, and price policy of French multinationals. In this segment, quality matters more than price in building business relations. A and P have no offices abroad, but they are also tightly linked to French high-class luxury brands, an option that is justified by highlighting the same advantages as mentioned by V. F, on the other hand, is more concerned with the American market and has opened an office in Miami to serve local riders and distributors. All the firms, generally speaking, try to choose their clients, rather than to be chosen by them and to develop cooperation all along the value chain.
The selected firms see the near future as a time of complexity, but also of renewed potentialities. Mastering complexity is considered the most serious challenge. Complexity is interpreted by interviewees as a trend in contemporary and future markets - products are becoming increasingly personalized and they have a shorter life in the context of stricter quality rules and global competition. Managing complexity requires constant mastering of new techniques, technological innovation, acquisition of skills and know-how, effective organization. Technology and human capital emerge, therefore, as two pillars for serving successfully the market. IT, for instance, is seen as a strategic tool for developing cooperation both with clients and suppliers, shortening distances, limiting transaction costs, ensuring partnerships rather that competition. Production technologies help to enhance quality and flexibility (Forza, 1997). Labor, however, is still viewed as a central competitive factor, and special attention is given to selection, training, and management of the workforce. For example, A introduced for all its employees 20-hour part-time shifts, which brought some positive results. Quality and productivity increased and at the same time stress and fatigue diminished. The firm also experienced remarkable gains in flexibility as it can now rapidly reset to regular time in case of higher demand. The workers' loyalty was improved as it would be difficult for them to find similar conditions in other firms. Major costs, determined by the increased number of workers and machines, have been partially absorbed by reduced profits and increased productivity.

Finally, all companies confirmed the positive role of the territory in their success in the global market. Although these firms are not officially based in recognized fashion districts, they are nevertheless located in areas hosting a relevant number of little shops working in the fashion system. Interviewees consider that this represents a very important competitive advantage as it adds flexibility, quality, and specialization through inter-firm cooperation; creates social networks allowing circulation of ideas, and therefore innovation; attracts major brands that can find diverse specialization within a limited space in the same production chain. The diminishing number of firms operating in the fashion sector is perceived as a major critical issue since it could jeopardize the 'territorial competitive advantage'. Another relevant challenge for the nearby future is to keep enough firms active on 
the territory. A very important goals is to communicate more effectively the tangible and intangible values of the 'made in Italy' brand and eventually the 'made in Vicenza' brand as a complex set of factors assuring the product's functional and aesthetic characteristics. This aspect is seen of utmost importance by the firms, which, even though they deliver a final product, don't have their own commercial brands. In this context, the value of the 'made in Italy' brand for the consumer is believed to strongly contribute to attracting international corporations of the fashion sector.

\section{Conclusions}

The research demonstrates that SMEs operating in particularly complex sectors such as the "fashion system" can compete successfully in global markets, provided that they develop strategies based on quality rather than price competition; succeed in positioning themselves in high level niches; build collaborative relationships all along the value chain; and exploit the territorially-based competitive advantages.

In the last twenty years, textile and accessories production went through a severe and long-lasting crisis, mainly due to the growing international competition from emerging countries, especially China, Eastern Europe, and Northern Africa. This trend deeply affected Italian production even in its traditionally strong clusters, such as the one located in Vicenza. Firms initially reacted to this challenge through such cost-saving strategies as delocalizing or investing in labour saving technologies to enhance efficiency. More recently, however, the factors as quality, innovation, and flexibility have emerged as the most relevant ones. This, in turn, opened new possibilities for SMEs to upgrade towards high-level market niches dominated by luxury fashion brands or to create very specific production, such as high-class sport outwear. Consolidation of their positions in such markets, building even tighter relations with demanding clients, and mastering the growing complexity of the modern world are seen as the main objectives of the time. These strategies allow the firms both to keep their business afloat and to continuously upgrade along the global value chains. In the meanwhile, the territory, industrial cluster and districts proved to be crucial in supplying the firms with additional competitive advantages. Operating within one territories allows SMEs to cooperate with each other, enhance their flexibility, promote products and ensure innovation, creating and diffusing original know-how, skills, and competences. Being located within a relatively small territory such as an industrial district, businesses are working in similar, complementary, or contiguous phases of the production chain and thus are able to attract international brands. Protecting the reputation of the "made in Italy" as a world-wide known brand linked to a specific territory and maintaining the vitality of handicrafts at territorial levels are, therefore, essential challenges for the near future. The study therefore demonstrates that small and medium handicrafts of the fashion system, though exposed to global concurrence, have still space and margins for long term development.

\section{References}

Balland, P.A. (2015). Proximity and Innovation: from Statics to Dynamics. Regional Studies, 49(6), 907-920. doi: 10.1080/00343404.2014.883598

BancaIntesa - SanPaolo, (2018). Economy and Finance of Industrial Districts. Annual Report n. 11 (in Italian).

Barzotto, M., Corò G., Volpe M. (2017). Global value chains and the role of MNEs in Local Production Systems. In V. De Marchi, E. Di Maria, G. Gereffi (Eds.), Local Production System, Local Clusters in Global Value Chains. Linking Actors and Territories Through Manufacturing and Innovation (pp. 94-114). New York: Routledge. doi: 10.4324/9781315182049

Belfanti, C.M. (2013). From rural Industries to Industrial Districts? The Case of Northern Italy from $16^{\text {th }}$ to $20^{\text {th }}$ century. In J.M. Minovez, C. Verna, L. Hilaire Pérez (Eds.) Rural Industries in Medieval and Modern Europe (pp. 295-308). Toulouse: Presses Universitaires du Mirail (in French).

Belfani, C.M. (2015). Renaissance and "Made in Italy": Marketing Italian Fashion through History (1949-1952). Journal of Modern Italian Studies, 20(1), 53-66. doi: $\underline{10.1080 / 1354571 X .2014 .973154}$

Belussi, F. (1992). Benetton Italy: Beyond Fordism and Flexible Specialization. The Evolution of the Network Firm Model. In: S. Mitter (Ed.), Computer-aided Manufacturing and Women's Employment: The Clothing Industry in Four EC Countries. (pp. 73-91). London: Springer. 
Bettinelli, C., Bergamaschi M., Kokash, R., \& Biffignandi. R. (2016). Process Innovation, Alliances, and the Interplay of Firm Age: Early Evidence from Italian Small Firms. International Business Research, 9(50), 86-99.

Bettiol, M. (2015). Telling the Made in Italy: A New Link Between Culture and Manufacturing (in Italian). Venezia: Marsilio Retrieved from https://tolinoreader.ibs.it/library/index.html\#/ epub?id=DT0245.9788831739504

Bettiol M., Chiarvesio M., Di Maria E., \& Micelli S. (2017). Manufacturing Comes Back? How Industrial Districts are Dealing with the New Globalization. Economia e Società Regionale = Regional Economy and Society, 25, 2, 55-64.

Bettiol M., Burlina C., Chiarvesion M., \& Di Maria E. (2017). Industrial Districts Firms do not Smile: Structuring the Value Chain between Local and Global. Advances in International Management, 30, 269-291.

Bettiol, M. et al. (2019). Globalization strategies and economic performance in Italian industrial district. In F. Puig, B. Urzelai (eds). Economic Clusters and Globalization: Diversity and Resilience. (pp. 113-134). Routledge: Abingdon.

Brioschi, F., Brioschi, M.S., \& Cainelli, G. (2002). From the Industrial District to the District Group. An Insight into the Evolution of Local Capitalism in Italy. Regional Studies. 36, 1037-1052. doi: $10.1080 / 0034340022000022521$

Buciuni, G., \& Pisano, G. (2018). Knowledge Integrators and the Survival of Manufacturing Clusters. Journal of Economic Geography, 18(5), 1-21. doi: 10.1093/jeg/lby035

Busato, A., \& Corò, G. (2011). District in the Crisis: Declining, Adapting or Innovating? Argomenti $=$ Arguments, 32, 71-84 (in Italian).

Cainelli, G. (2008). Industrial districts: theoretical and empirical insights. In C. Karlsson (Ed.). Handbook of Research on Cluster Theory (pp. 189-202). Cheltenham: Edard Elgar

Camagni, R., \& Capello, R. (2013). Regional Competitiveness and Territorial Capital: a Conceptual Approach and Empirical Evidence from the European Union. Regional Studies, 47(9), 1383-1402. doi: 10.1080/00343404.2012.681640

Caracausi, A. (2017). Information asymmetries and craft guilds in pre-modern markets: evidence from Italian proto-industry. Economic History Review, 70 (2), 397-422. doi: 10.1111/ehr.12380

Celetti, D. (2015). Peasants' Destinies. Rural Families and Economic Transformations. In Frabrice Boudjaba (Ed.). Work and rural Families (pp. 225-244). Rennes: PUR (in French).

Celetti, D. (2019). Diffused Urbanization and Industrial Cluster in North-Eastern Italy: why Territory still matters in the Globalized World Economy?. In I. Turghel, H. Wiesmeth, V. Beker (Eds.). XIV International Conference Russia Regions in the Focus of Change - Book of Proceedings (pp. 162-171). Ekaterinburg: URFU.

Celetti, D. (2019b). Italian Handicrafts in the Eurasian Markets. A Case Study from the Ceramic Cluster of Nove-Bassano (Vicenza-Italy). The Journal of Economic Research and Business Administration, 128(2), 189-197.

Confartigianato Imprese (2018). Studies Fashio. 11 July 2018 - In Italian. Retrieved from https:// www.confartigianato.it/2018/07/studi-moda

Coro', G., \& Grandinetti, R. (1999). Evolutionary patterns of Italian industrial districts. Human Systems Management, 18, 117-129.

Coro', G., \& Micelli, S. (2007). The Industrial District as Local Innovation Systems. In Sadun A. Italy in the International Economy since the Second World War (pp. 425-458). Soveria Mannelli: Rubettino.

Coro', G., \& Grandinetti, R. (2010). Frontiers and actors of development beyond the crisis: the laboratory of North-Eastern Italy. Economia e Societa' Regionale = Regional Economy and Society, 2, 43-63.

Corò, G., Schenkel, M., \& Volpe, M. (2013). International Offshoring, Local Effects: An Inquiry on Italian Firms. Symphonya, 2, 1-13.

Coro, G. (2018). Italian industry in the new globalization. Lindustria, 39, 347-356. doi: $\underline{10.1430 / 92509}$

Coro', G., Schenkel, M., \& Volpe, M. (2007). North Eastern Italy: Lookong for the lost model. L'industria = The Industry, 3, 441-461 (in Italian). 
Dunford, M. (2006). Industrial Districts, Magic circles, and the Restructuring of the Italian Textile and Clothing Chain. Economic Geographic. 82(1), 27-59.

Favero, G. (2012). The Network firm as Instrument of Risk Minimization: The Benetto Case. In Les sociétés méditerranéennes face au risque: économies (pp. 215-222). Il Cairo: Institut Française d'Archéologie Orientale (in Italian).

Ferrario, V. (2013). Cultivated Spaces (Multifunctional). The Rural Space in the Transformation of contemporary cities. In A. Magnier, M. Morandi (Eds.). Landscapes in Transformation. The Landscape approach to the Tansformation of the European City. Milano: Franco Angeli (in Italian).

Fontana, G.L. (2004). Entrepreurs, Enteprises and Territories from the First to the Second Industrial Revolution. In G.L. Fontana (Ed.), The Vicenza's Industry from the Middle Ages to Nowadays (pp. 347-454). Padova: Cleup (in Italian).

Fontana, G.L., \& Riello, G. (2005). Seamless industrialization: The Lanificio Rossi and the Modernization of the Wool Industry in Nineteenth Century Italy. Textile History, 36(2), 168-195. doi: $\underline{10.1179 / 004049605 \times 61555}$

Fontana, G.L, Panciera, W., \& Riello, G (2009). The Italian textile industry, 1600-2000: labour, sectors and products. In L.H. Van Voss, E. Hiemstra-Kuperus, E. Van Nederveen Meerkerk (Eds.). The Ashgate Companion to the History of Textile Workers, 1650-2000 (pp. 275-303). Ashgate, Farnham.

Fontana, G.L. (2010). Made in Italy: between past and future. In G. Riello, P. Mcneil (Eds.). The Fashion History Reader. Global Perspectives (pp. 543-545). London, New York: Routledge.

Forza, C., \& Vinelli, A. (1997). Quick Response in the Textile-apparel industry and the Support of Information Technologies. Integrated Manufacturing Systems, 9(8), 125-136. doi: $\underline{10.1108 / 09576069710181947}$

Gilmore, J.H, \& Pine, J. (2007), Authenticity: what Consumers Really want. Boston: Harvard Business School Press.

Ketelhöhn, W. (1993). What do we mean by cooperative advantage? European Management Journal, 11(1), 30-37. doi: 10.1016/0263-2373(93)90021-9

Lacquement, G., \& Chevalier, P. (2016), Territoire et développement des territoires locaux, enjeux théoriques et méthodologiques de la transposition d'un concept de l'économie territoriale a l’analyse géographique. Annales de geographie, 711(5), 490-518.

Leoni, G. (2017), Social responsibility in Practice: an Italian Case from the early $20^{\text {th }}$ Century. Journal of Management History, 23(2), 133-151. doi: 10.1108/JMH-10-2016-0057

Lees-Maffei, G., \& Fallan K. (2014). Made in Italy: Rethinking a Century of Italian Design. London: Bloomsbury.

Magnani, G., Zucchella, A., \& Strange, R. (2019). The Dynamics of Outsourcing Relationships in Global Value Chains: Prespectives from MNEs and Their Suppliers. Hournal of Business Research, $103,581-595$.

Mariotti I., Barzotto M., Coro' G., Saloriani S. (2020). Industrial Districts, Urban Areas or both? The Location Behaviour of Foreign and Domestic Firms in an Italian Manufacturing Region. The Annals of Regional Science. Special Issue Paper, 1-24. doi: 10.1007/s00168-020-00990-8

Merlo, E. (2011). Italian fashion business: Achievements and Challenges (1970s-2000s). Business History. 53(3), 344-362. doi: 10.1080/00076791.2011.565512

Merlo, E. (2012). The ascendance of the Italian fashion brands (1970-2000). In L. Segreto, H. Bonin, A.K. Kozminski, \& C. Manera (Eds.), European business and brand building (pp. 137-154). Brussels: PIE Peter Lang.

Merlo E. (2015). 'Size Revolution': The Industrial Foundation of the Italian Clothing business. Business History, 57(6), 919-941. doi: 10.1080/00076791.2014.992336

Merlo, E. (2018) Italian Luxury Goods Industry on the Move: SMEs and Global Value Chains. In: P.Y. Donzé, R. Fujioka (Eds.), Global Luxury (pp. 39-63). Singapore: Palgrave. doi: 10.1007/978981-10-5236-1 3

Mistri M. (2009). The industrial district as a local evolutionary phenomenon. In G. Becattini, M. Bellandi, L. De Propris (Eds.), A Handbook of Industrial Districts (pp. 193-203). Cheltenham: Elgar. 
Ortega-Colomer, Francisco Javier, Molina-Morales, Francesc Xavier, Fernández de Lucio, Ignacio. (2016). Discussing the Concepts of Cluster and Industrial District. Journal of technology management \& innovation, 11(2), 139-147. doi: 10.4067/S0718-27242016000200014

Palan, N. (2010). Measurement of Specialization. The choice of Indices, FIW Working Paper. December, $1-38$.

Paris, I. (2006). Stitched objects. Ready-made clothing in Italy from the first post-war period to the 1970s. Milano: Franco Angeli (in Italian).

Porter, M.E., Ketels, C.H.M. (2009). Clusters and Industrial Districts: Common Roots, Different Perspectives. In G. Becattini, M. Bellandi, L. De Propis (Eds.) A Handbook of Industrial Districts (pp. 172-183). Cheltenham: Edward-Edgar.

Riello, G. (2013). The Italian Textile Industry, 1600-2000. Labour, Sectors, and Products. In The Ashgate Companion to the History of Textgile Workers. 1650-2000 (pp. 247-304). Farnham: Ashgate.

Roverato, G. (2004). Vicenza's Industry in the $20^{\text {th }}$ century. In G.L. Fontana (ed.) History of Vicen$z a$ 's Industry from Medieval Time to the Present (pp. 455-543). Padova: Cleup (in Italian).

Rovizzi, L., \& Thomson, D. (1992). Fitting Company Strategy to Industry Structure: A Strategic Audit of The Rise of Benetton and Stefanel. Business Strategy Review, 3(3), 73-99. doi: 10.1111/ j.1467-8616.1992.tb00036.x

Scarpellini, E. (2019). Italian Fashion since 1945: a Cultural History. Champ, Plagrave.

Tait, N. (1998). From small-scale weaving to world-leading. Apparel International. 29(7), 10-11.

Tattara, G., \& Crestanello, P. (2011). Industrial Cluster and the Governance of the Global Value Chain. The Romania-Veneto Network in Footwear and Clothing. Regional Studies, 45(2), 187-203. doi: $\underline{10.1080 / 00343401003596299}$

Volpe, M., Corò, G., \& Schenkel, M. (2012). International Openness and Structural Change in the Manufacturing Systema of North Eastern Italy. L'industria, 1, 193-204 (in Italian).

Whitford J. (2001). The decline of a model? Challenge and response in the Italian Industrial Districts. Economy and Society, 30, 38-65.

\section{Information about the author}

David Celetti - PhD in Economic History, Research Professor, Professor of Local Development, Chair of Economic History, at the Department of Historical, Geographical Sciences and of the Antiquity of the University of Padua (Via 8 Febbraio 1848, 2, 35122 Padova, Italy); e-mail: david.celetti@unipd.it

ARTICLE INFO: received March 9, 2020; accepted May 5, 2020

\section{Информация об авторе}

Челетти Давид - $\mathrm{PhD}$ в экономической истории, профессор-исследователь, профессор департамента исторических, географических наук и древности Падуанского университета (35122, ул. 8 февраля 1848, 2, Падуя, Италия); e-mail: david.celetti@unipd.it

ИНФОРМАЦИЯ О СТАТЬЕ: дата поступления 9 марта 2020 г.; дата принятия к печати 5 мая 2020 г. 